УДК 378.091.212:005.963

(C) Лунячек В. Е., Рубан Н. П., 2020

https://orcid.org/0000-0002-4412-7068

https://orcid.org/0000-0001-8337-2739

https://doi.org/10.34142/23128046.2020.49.13

В. Е. Лунячек

Н. П. Рубан

\title{
ПІДВИЩЕННЯ КВАЛІФІКАЦІЇ НАУКОВО-ПЕДАГОГІЧНИХ ПРАЦІВНИКІВ ЗАКЛАДІВ ВИЩОЇ ОСВІТИ В СФЕРІ ІНТЕЛЕКТУАЛЬНОЇ ВЛАСНОСТІ: ЗАКОНОМІРНОСТІ, ПРИНЦИПИ, ПЕДАГОГІЧНІ УМОВИ ТА ОСНОВИ ТЕХНОЛОГІЇ
}

У роботі обтрунтовано основні теоретичні засади підвищення кваліфікацї науково-педагогічних працівників закладів вищзӧ освіти у сфері охорони $i$ захисту прав інтелектуальної власності. 3 а результатами проведеного аналізу доведено, щзо в сучасній педагогіщуі, зокрема педагогійі вищцої школи достатньо трунтовно розроблені науково-теоретичні засади прочесу підвищення кваліфікаџії працівників освіти, разом із тим нагальною потребою часу $\epsilon$ їх подальша розробка в контексті формування окремих компетентностей за актуальними сьогодні напрямами, одним із яких $\epsilon$ охорона $і$ захист прав інтелектуальної власності. Висвітлені відповідні закономірності, принципи, педагогічні умови. Окрема увага приділена педагогічній технологіі підвищення кваліфікації науково-педагогічних працівників у сфері охорони $і$ захисту прав інтелектуальної власності, яка висвітлена за етапами: підготовчо-діагностичним, мотиваційно-цуільовим, когнітивним, процесуально-діяльнісним, оцінно-корекиійним.

У роботі наведено орієнтовний перелік цілей науково-педагогічних працівників щзодо формування в них компетентності в сфері охорони $і$ захисту прав інтелектуальної власності. Наведено також декілька варіантів навчальних планів, зокрема, навчальні плани, щзо розраховані на 30 годин (1 кредит) i 180 годин (6 кредитів), які дозволяють сформувати уявлення науково-педагогічного працівника шуодо охорони $i$ захисту прав інтелектуальної власності на його авторські напраџювання та напрацювання студентів. Запропоновано також алгоритм підвищення кваліфікації науковопедагогічних працівників у сфері охорони $і$ захисту прав інтелектуальної власності, наведено структуру та зміст окремих компетентностей, щуо складають інтегральну компетентність науково-педагогічного працівника в сфері охорони $i$ захисту прав інтелектуальної власності, приклад компетентнісної задачі за темою «Набуття прав інтелектуальної власності» $i$ тестових завдань за темою «Система управління інтелектуальною 
власністю в Україні», щуо використовуються в процесі підвищення їх кваліфікації. Наведено приклад дистанційного курсу "Підвищення кваліфікації методики управління об'єктами інтелектуальної власності».

Ключові слова: алгоритм підвищення кваліфікації, заклад вищої освіти, закономірності процесу підвищення кваліфікащії, інтелектуальна власність, науково-педагогічний працівник, педагогічна технологія, педагогічні умови.

Luniachek V.E., Ruban N.P. Advanced training of scientific and pedagogical employees of higher educational institutions in the field of intellectual property: regularities, principles, pedagogical conditions and fundamentals of technology. The main theoretical bases of advanced training of academics in the field of protection of intellectual property rights are substantiated in the paper. According to the results of the analysis it is proved that in modern pedagogy, and in higher education pedagogy in particular, scientific and theoretical bases of the process of professional development of educators are thoroughly developed, however there is the urgent need for their further development in the context of practical skills development in the relevant modern directions, one of which is protection of intellectual property rights. Relevant regularities, principles, pedagogical conditions are covered. Special attention is paid to the pedagogical technology of professional development of scientific and pedagogical staff in the field of protection of intellectual property rights, which is covered according to the following stages: preparatory-diagnostic, motivational-target, cognitive, procedural-activity, evaluation-correctional.

The paper provides an indicative list of goals of research and teaching staff regarding the formation of their competence in the field of protection and enforcement of intellectual property rights. There are also several variants of curriculum, in particular, curriculum designed for 30 hours (1 credit) and the one for 180 hours (6 credits), which allow for the researcher to form the understanding of the protection and enforcement of intellectual property rights on their research work and work of students. An algorithm for professional development of research and teaching staff in the field of protection and enforcement of intellectual property rights is proposed, the structure and content of individual competencies that make up the integrated competence of research and teaching staff in the field of protection and enforcement of intellectual property rights are suggested, a sample competence task on the topic "Intellectual Property Right Acquisition" and a set of test tasks on the topic "Intellectual Property Management System in Ukraine ", which are used in the process of professional training, are given. An example of a distance learning course "Advanced Training in the Methodology of Intellectual Property Management " is provided.

Keywords: algorithm of advanced training, institution of higher education, regularities of the process of advanced training, intellectual property, scientific and pedagogical staff, pedagogical technology, pedagogical conditions. 
Вступ. Потреби професійного розвитку науково-педагогічних працівників на сучасному етапі розвитку вищої освіти в Україні актуалізували низку важливих питань, пов'язаних не тільки 3 диверсифікацією процесів підвищення їх кваліфікації, а й із формуванням компетентностей за окремими напрямами, що $\epsilon$ на часі, зокрема у сфері охорони й захисту прав інтелектуальної власності. Подальший розвиток України, як сучасної держави, що $є$ повноправним гравцем на світових ринках в умовах глобалізації, $\epsilon$ неможливим без стимулювання інноваційних процесів у державі та їх правової підтримки, зокрема й охорони та захисту відповідних інтелектуальних напрацювань.

Основи цього процесу повинні закладатися ще під час професійної підготовки нового покоління в закладах вищої освіти (3ВО). Разом із тим, ми маємо суттєве протиріччя між потребою у відповідній професійній компетентності науково-педагогічних працівників, які повинні опікуватися цим питанням та реальним станом їх спроможності виконати це завдання, що підтверджено сьогодні низкою досліджень за цією тематикою (Luniachek, Ruban \& Brovdii, 2020; Luniachek, Ruban \& Fesenko, 2018). Подолання цього протиріччя потребує розробки теоретичних основ цього процесу, зокрема формулювання закономірностей, принципів, педагогічних умов та основ відповідної технології.

Сьогодні в Україні в цілому сформовано науково-теоретичне підгрунтя процесу підвищення кваліфікації педагогічних кадрів у нових умовах після вступу в дію Законів України «Про освіту» № 2145-VIII від 05.09.2017 р. (із останніми змінами № 910-IX від 17.09.2020р.), «Про вищу освіту» № 1556-VII від 1 липня 2014 року (із останніми змінами № 849-IX від 02.09.2020 р.) (Prezydent Ukrainy, 2014; Prezydent Ukrainy, 2017). та Постанови КМ України № 800 від 21 серпня 2019 року «Деякі питання підвищення кваліфікації педагогічних і науково-педагогічних працівників» (із змінами № 1133 від 27.12.2019 р.) (Kabinet Ministriv Ukrainy, 2019). Це роботи таких авторів, як: В.Берека, С.Бєляєв, Ю.Завалевський, Г.Литвинюк, Л. Мозгова; М. Москалець, О. Похиляк, Г.Свінних, М. Скрипник, В. Сидоренко, Т.Сорочан, В. Швидун та ін. (Bieliaiev, 2019; Zavalevskyi, 2014; Moskalets \& Shvydun, 2018; Bereka, 2017; Sydorenko \& Skrypnyk, 2017; Sorochan, 2019; Shvydun, 2019).

Певний внесок зробили і автори цієї статті, що знайшло своє відображення у трьох монографічних дослідженнях. У цих роботах акцент робиться саме на підвищенні кваліфікації працівників середньої і вищої освіти в сфері охорони і захисту прав інтелектуальної власності (Luniachek, Ruban \& 
Brovdii, 2020; Luniachek, Ruban \& Fesenko, 2018; Kovalenko, Luniachek, Fesenko, Timaniuk, Rubashka, Ruban, Brovdii \& Kulakovskyi, 2020).

Разом із тим розробка теоретичних засад процесу підвищення кваліфікації працівників освіти, зокрема науково-педагогічних працівників триває. Як ми наголошували вище важливою іiі складовою $\epsilon$ розробка закономірностей, принципів, педагогічних умов та основ відповідної технології. Закономірності навчання за В. Бондарем, - це теоретична основа існування явищ об'єктивної дійсності, регулювання ефективного перебігу певного процесу, практичної діяльності людини. Закономірності навчання не містять прямих указівок i рекомендацій, як діяти в конкретних ситуаціях, a $\epsilon$ теоретичною базою для розробки й обгрунтування способів дій і поведінки людини на рівні принципів, правил, вимог, традицій. Він пише, що закони й закономірності в педагогіці відображають істотні, стійкі, повторювальні та необхідні зв'язки між явищами об'єктивної дійсності, сутність яких або ж досліджується, або ж вивчається (Kremen, 2008). М. Фіцула розглядає закономірності навчання як об'єктивні, стійкі й істотні зв'язки у навчальному процесі, що зумовлюють його ефективність (Fitsula, 2000).

Залежність між об'єктивними закономірностями навчального процесу i цілями відображають принципи навчання. Сьогодні принцип визначають, як основне, вихідне положення будь-якої теорії, учіння та ін.; керівну ідею, основне правило діяльності (Slovar inostrannyh slov, 1987). Разом із тим В. Бондар вказує, що, оскільки прояв дії тих чи інших законів і закономірностей у дидактичних процесах прихований, нормативний перебіг будь-якого виду діяльності гарантують принципи навчання і принципи дидактики, в суті яких проявляється дія відповідних законів і закономірностей (Kremen, 2008). В. Михайловський під принципом навчання у вищій школі розуміє основне, вихідне положення, керівну ідею або правило діяльності (Mihajlovskij, 1991).

Щодо педагогічних умов, то, за Т. Гуцан, - це структурна оболонка педагогічних технологій чи педагогічних моделей; завдяки педагогічним умовам реалізуються компоненти технології (Hutsan, n. d.). О. Мойсеєв та інші визначають умови як цілеспрямований і результативний вплив на об'єкти, якими управляють (Moiseev \& Hvan, 2005).

Разом із тим ми погоджуємося з М. Поташником та іншими дослідниками, які пишуть, що цінності, цілі, провідні педагогічні й управлінські ідеї, постулати, парадигми необхідні, але без знання технологій вони не можуть бути здійснені і не дадуть очікуваного результату (Potashnik \& Moiseev, 1997). С. Бєляєв пише, що у зв'язку з необхідністю забезпечення конкретизованих результатів 
освітнього процесу професійна підготовка має набути ознак органічно інтегрованої до системи професійної підготовки технології (Bieliaiev, 2019). Г. Селевко вказує, що педагогічна (освітня) технологія - це система функціонування всіх компонентів педагогічного процесу, яка побудована на науковій основі, запрограмована в часі і в просторі та веде до намічених результатів (Selevko, 2005). П. Олійник підкреслює, що зміст наукового терміна «педагогічна технологія» містить модель, обгрунтовану в логічній послідовності систему, яка реалізується в практичній діяльності. Структуру будь-якої педагогічної системи становлять такі взаємопов'язані елементи:

- мета навчання та зміст навчально-пізнавальної діяльності;

- елементи дидактичної системи та їх ієрархічна послідовність (принципи, правила навчання, форми, методи, засоби);

- методологічні основи процесу навчання;

- контингент викладачів та студентів (Honcharenko, Oliinyk \& Fedorchenko, 2003).

Сьогодні в значній кількості наукових праць представлена стандартна структура педагогічної технології, яка складається з таких етапів:

- підготовчо-діагностичний;

- мотиваційно-цільовий;

- когнітивний;

- процесуально-діяльнісний;

- оцінно-корекційний (Kuruch, 2019; Luniachek, 2012; Mirshuk, 2016; Chebotarova, 2018).

Наприкінці теоретичного огляду слід послатися на тезу С. Бєляєва, що поступове виокремлення в самостійне методологічне вчення технологічний підхід отримав завдяки специфічним передумовам свого розвитку, внаслідок чого педагогічна технологія стала об'єднувальним терміном для нових наукових підходів до аналізу та організації педагогічного процесу в ході вирішення низки проблем, пов'язаних із аналізом навчального матеріалу та організацією педагогічної взаємодії суб'єктів освітнього процесу (Bieliaiev, 2019).

Мета та завдання. Метою роботи є розробка теоретичних основ процесу підвищення кваліфікації науково-педагогічних працівників у сфері охорони і захисту прав інтелектуальної власності, зокрема формулювання закономірностей, принципів, педагогічних умов та основ відповідної технології. 
Методи дослідження. 3 метою вирішення висунутих завдань використовувалися такі методи дослідження, які систематизовано на таких рівнях:

- теоретичному: методи системного аналізу науково-педагогічної, науково-методичної літератури для теоретичного узагальнення основних підходів щодо розв’язання комплексної соціально-педагогічної проблеми підвищення кваліфікації науково-педагогічних працівників 3ВО у сфері охорони i захисту прав інтелектуальної власності. Застосування методу факторно-критеріального моделювання дозволило створити кваліметричні моделі оцінювання рівня професійної компетености НПП ЗВО у сфері охорони i захисту прав інтелектуальної власності на оцінно-корекційному етапі наведеної в роботі технології. Завдяки системно-узагальнювальному методу було здійснено теоретичне узагальнення результатів дослідної роботи;

- емпіричному: прогностичні методи (експертних оцінок, узагальнення незалежних характеристик), діагностичні методи (анкетування, тестування, бесіди, опитування), обсерваційні методи (спостереження, самоспостереження, самооцінювання) для виявлення рівня компетентності НПП ЗВО у сфері охорони і захисту прав інтелектуальної власності.

Результати. У процесі реалізації завдань дослідження нами були сформульовані закономірності процесу підвищення кваліфікації науковопедагогічних у сфері охорони і захисту прав інтелектуальної власності:

1. Ефективність модернізації процесу підвищення кваліфікації науковопедагогічних працівників ЗВО в Україні згідно 3 існуючими світовими тенденціями суттєво залежить від сформованості їх окремих компетентностей у межах відповідної компетентнісної моделі. Однією з таких компетентностей $є$ спроможність у наукових, методичних та інших інноваційних розробках виявляти, охороняти і захищати об’єкти інтелектуальної власності.

2. Ефективність підвищення кваліфікації науково-педагогічних працівників 3ВО у сфері інтелектуальної власності визначається правильним застосуванням певних методологічних підходів у цьому процесі, зокрема системного, діяльнісного, кваліметричного, андрагогічного, компетентнісного та інших.

3. Результативність процесу підвищення кваліфікації науковопедагогічних працівників ЗВО залежить від відповідності змістовного наповнення спеціальних навчальних дисциплін, тренінгів тощо. 
4. Результативність процесу підвищення кваліфікації науковопедагогічних працівників ЗВО залежить від грунтовності розробленої педагогічної технології.

5. Ефективність процесу підвищення кваліфікації науково-педагогічних працівників ЗВО залежить від комплексу педагогічних умов, необхідних для досягнення цілей.

Педагогічними умовами, від яких залежить ефективне формування компетентності науково-педагогічних працівників ЗВО у сфері охорони i захисту прав інтелектуальної власності, є такі:

1. Підвищення кваліфікації науково-педагогічних працівників щодо формування в них компетентності у сфері охорони і захисту прав інтелектуальної власності має функціонувати як цілісна система, що $\epsilon$ складовою професійного розвитку працівника $3 \mathrm{BO}$, завдяки розробці відповідної технології.

2. Підвищення кваліфікації науково-педагогічних працівників щодо формування в них компетентності у сфері охорони i захисту прав інтелектуальної власності повинна бути спрямована на становлення їх як суб'єктів цього процесу.

3. Підвищення кваліфікації науково-педагогічних працівників щодо формування в них компетентності у сфері охорони i захисту прав інтелектуальної власності передбачає наявність певного алгоритму, наукового, навчально-методичного та організаційного забезпечення.

4. Підвищення кваліфікації науково-педагогічних працівників щодо формування в них компетентності у сфері охорони i захисту прав інтелектуальної власності передбачає наявність відповідного кадрового забезпечення процесу навчання, зокрема осіб, які мають спеціальну освіту в сфері інтелектуальної власності, наприклад за спеціальністю 073 Менеджмент ОПП «Управління інтелектуальною власністю».

5. Підвищення кваліфікації науково-педагогічних працівників щодо формування в них компетентності у сфері охорони і захисту прав інтелектуальної власності передбачає відповідне матеріально-технічне і фінансове забезпечення.

Педагогічну технологію формування компетентності науковопедагогічних працівників у сфері охорони і захисту прав інтелектуальної власності розглянемо за етапами.

Підготовчо-діагностичний етап технології формування компетентності науково-педагогічних працівників у сфері охорони i захисту прав 
інтелектуальної власності в процесі підвищення кваліфікації передбачає проведення серії діагностичних процедур, які дозволять зрозуміти реальний стан готовності науково-педагогічних працівників до формування зазначеної компетентності.

Сучасна наукова література визначає педагогічну діагностику як процес установлення й вивчення ознак, що характеризують різні елементи педагогічної системи, й умов iї функціонування для прогнозування можливих тенденцій розвитку, відхилень, запобігання заходами педагогічної корекції небажаних тенденцій і стимулювання позитивних елементів розвитку (особистості, групи, педагогічних явищ) (Majorov, 2005). У сучасних умовах для педагогічної діагностики в окресленій нами сфері доцільно використовувати, крім традиційних опитувань вхідного стану сформованості відповідної компетентності, також і стандартні гугл-інструменти, які дозволяють сьогодні більш оперативно опитати потенційних отримувачів освітньої послуги 3 підвищення кваліфікації у сфері охорони і захисту прав інтелектуальної власності. Наголосимо на важливості розроблення адекватного інструментарію, що використовується для відповідної діагностики. Відповідний інструментарій розроблений авторами разом із колегами кафедри креативної педагогіки й інтелектуальної власності Української інженерно-педагогічної академії та відображений у роботах (Ukrainska inzhenerno-pedahohichna akademiia, 2019; Luniachek, Ruban \& Brovdii, 2020; Luniachek, Ruban \& Fesenko, 2018).

Мотивачійно-цільовий етап $€$ важливою складовою технології формування компетентності науково-педагогічних працівників у сфері охорони і захисту прав інтелектуальної власності в процесі підвищення кваліфікації. М. Мескон та інші дослідники пишуть, що цілі повинні мати певні характеристики - бути конкретними i підлягати вимірюванню, бути зорієнтованими в часі (мати довгостроковий, середньостроковий i короткостроковий характер), передбачати можливість реального їх досягнення (Meskon, Albert \& Hedouri, 1994).

У розробленій авторами технології - постановка цілей базується на основних положеннях компетентнісного підходу (Luniachek, 2013). Створення та реалізація зазначеної технології передбачає формування компетентності щодо спроможності науково-педагогічних працівників виявляти, охороняти i захищати OІВ у методичних, наукових, інноваційних розробках тощо. У межах цього етапу відбувається побудова науково-педагогічним працівником особистісного дерева цілей його професійного розвитку, зокрема й у сфері охорони і захисту прав інтелектуальної власності (табл.1). 
Орієнтовний перелік цілей НПП щодо формування компетентності в сфері охорони і захисту прав IB

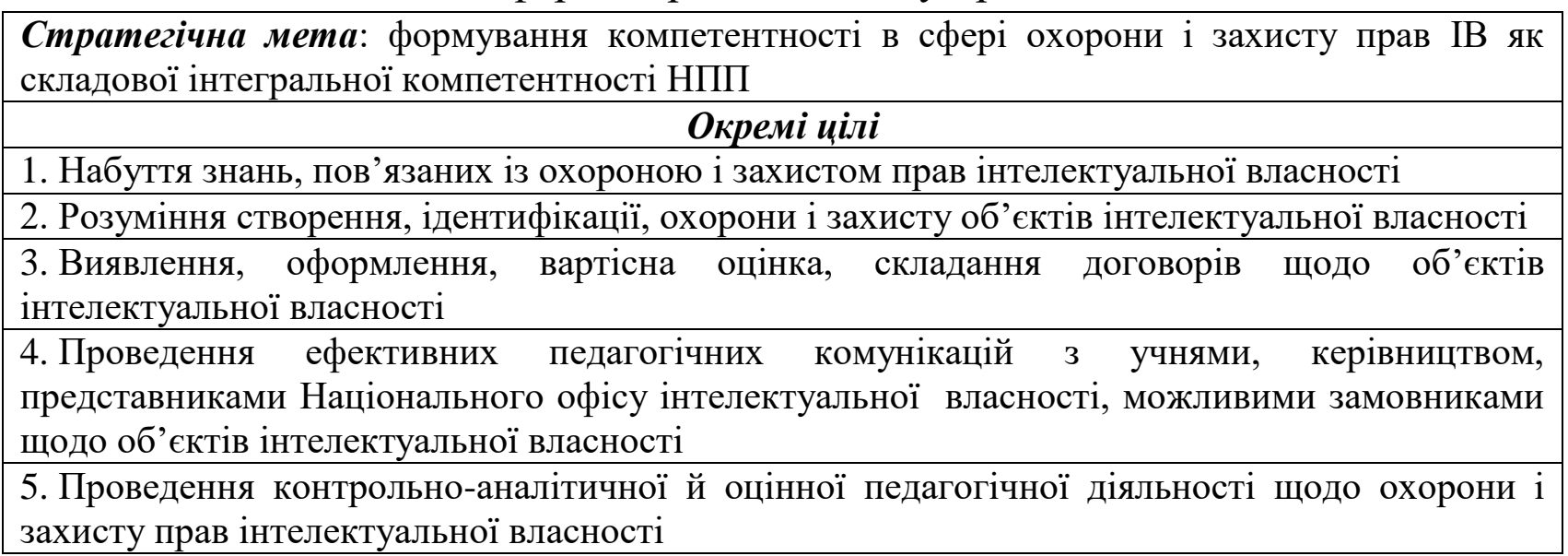

Разом із тим, зазначений процес відбувається в межах побудови дерева цілей для всього ЗВО, його місії. Формування в науково-педагогічних працівників компетентності у сфері охорони і захисту прав інтелектуальної власності дозволить не тільки захистити їм власні авторські розробки, а й виступить каталізатором інноваційних процесів у ЗВО. Частково цю проблематику ми відобразили в таких роботах (Luniachek, Ruban \& Brovdii, 2020; Luniachek, 2020; Luniachek, Ruban \& Fesenko, 2018; Luniachek, 2017; Luniachek \& Ruban, 2020; Luniachek, 2016; Luniachek \& Varenko, 2018).

Когнітивний eman технології передбачає вдосконалення змістової підготовки науково-педагогічних працівників у процесі підвищення кваліфікації щодо формування в них компетентності у сфері охорони і захисту прав інтелектуальної власності. Із цією метою пропонується запровадження спеціально створених навчальних планів, розрахованих на різну кількість кредитів. У цій роботі ми наведемо кілька варіантів навчальних планів, зокрема навчальний план, розрахований на 30 годин (1 кредит), який дозволяє сформувати уявлення НПП в цілому щодо охорони і захисту прав IB на його авторські напрацювання (табл.2.)

Таблиця 2

Навчальний план модулю «Система інтелектуальної власності в Україні» для підвищення кваліфікації НПП (1 кредит)

\begin{tabular}{|l|l|c|c|c|c|}
\hline \multirow{2}{*}{$\begin{array}{l}\text { № } \\
\text { 3/ } \\
\Pi\end{array}$} & Тема & \multicolumn{4}{|c|}{ Кількість годин } \\
\cline { 2 - 7 } & $\begin{array}{l}\text { Інститут авторського права: об’єкт і суб’єкт, їх охорона та } \\
\text { захист }\end{array}$ & 2 & 2 & 6 & 10 \\
\hline
\end{tabular}




\begin{tabular}{|l|l|c|c|c|c|}
\hline 2. & $\begin{array}{l}\text { Інститут патентного права: об’єкт і суб’єкт, їх охорона та } \\
\text { захист }\end{array}$ & 2 & 2 & 6 & 10 \\
\hline 3. & Передача прав інтелектуальної власності & 2 & 2 & 6 & 10 \\
\hline Всього & 6 & 6 & 18 & 30 \\
\hline
\end{tabular}

Крім того, авторами було розроблено навчальний план на 180 годин (6 кредитів), який дозволяє в повній мірі сформувати компетентність науковопедагогічного працівника у сфері охорони і захисту прав інтелектуальної власності. Цей план замовник відповідної освітньої послуги може виконати як одноразово, так і протягом 5 років, під час нормативно-обумовленого циклу підвищення кваліфікації (табл.3).

Таблиця 3

Навчальний план підвищення кваліфікації НПП (6 кредитів) за напрямом «Управління об’єктами інтелектуальної власності в 3ВО»

\begin{tabular}{|c|l|c|c|c|c|}
\hline \multirow{2}{*}{$\begin{array}{c}\text { № } \\
3 /\end{array}$} & \multicolumn{1}{|c|}{ Тема } & \multicolumn{3}{|c|}{ Кількість годин } \\
\cline { 2 - 7 }
\end{tabular}

Підкреслимо, що інтегральна компетентність науково-педагогічного працівника в сфері охорони і захисту прав інтелектуальної власності складається з окремих компетентностей. Нижче у таблиці 4 наведено структуру та зміст компетентності щодо охорони і захисту прав інтелектуальної власності НПП ЗВО.

Таблиця 4

Структура та зміст компетентностей щодо охорони і захисту прав інтелектуальної власності НПП ЗВО

\begin{tabular}{|c|c|}
\hline Структура & Зміст \\
\hline Знання & $\begin{array}{lccc}\text { - } & \text { Розуміння важливості не порушувати авторські права при } \\
\text { виконанні професійних завдань та під час роботи в мережі Інтернет. } \\
-\quad \text { Знання } & \text { вимог статті } 42 & \text { Закону України } & \text { «ро освіту», що } \\
\text { передбачає } & \text { дотримання } & \text { академічної } & \text { доброчесності }\end{array}$ \\
\hline
\end{tabular}




\begin{tabular}{|c|c|}
\hline & 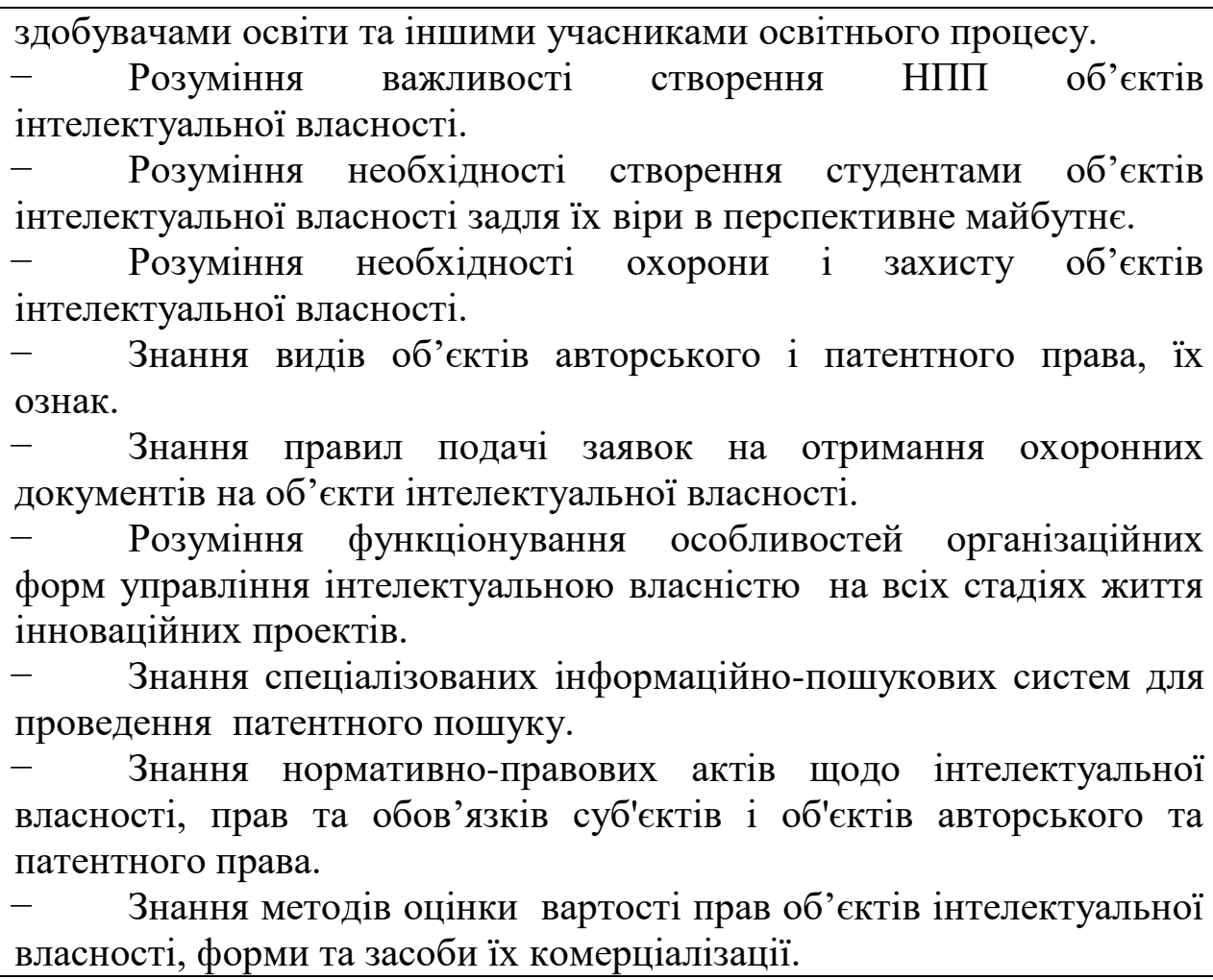 \\
\hline Уміння & 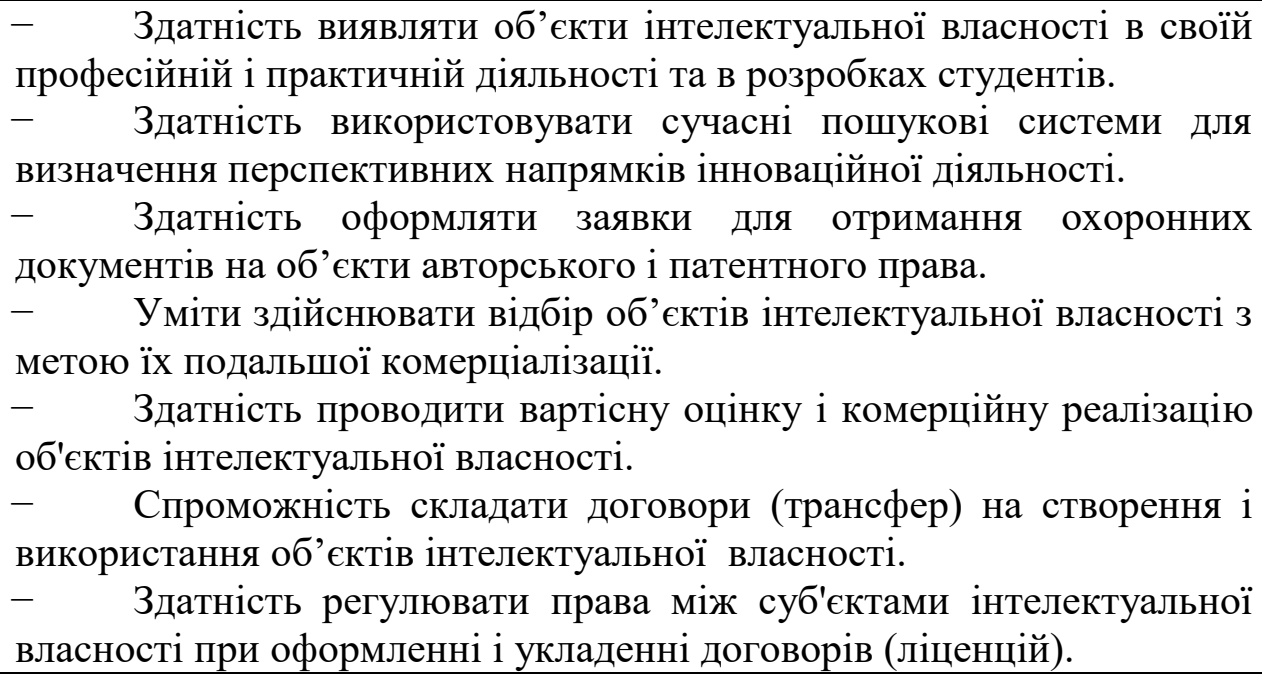 \\
\hline Комунікація & $\begin{array}{l}\text { - Будувати комунікації зі студентами задля створення ними } \\
\text { об’єктів інтелектуальної власності. } \\
-\quad \text { Будувати комунікації } 3 \text { керівництвом } 3 \text { ВО задля охорони і } \\
\text { захисту прав інтелектуальної власності. } \\
-\quad \text { Використовувати комунікацію } 3 \text { Національним офісом } \\
\text { інтелектуальної власності (НОІВ) задля оформлення охоронних } \\
\text { документів і договорів щодо об’єктів інтелектуальної власності. } \\
-\quad \text { Використовувати комунікацію } 3 \text { можливими замовниками } \\
\text { щодо передачі прав на об'єкти інтелектуальної власності. }\end{array}$ \\
\hline $\begin{array}{l}\text { Автономність } \\
\text { відповідальність }\end{array}$ & $\begin{array}{l}\text { - Спроможність оцінювати творчі роботи учнів, застосовувати } \\
\text { сучасні методи оцінки творчих завдань. } \\
-\quad \text { Спроможність аналізувати навчальний процес } 3 \text { метою } \\
\text { виявлення об'єктів інтелектуальної власності в своїй професійній і } \\
\text { практичній діяльності та в розробках студентів. } \\
\text { - Спроможність аналізувати і оцінювати власні розробки і }\end{array}$ \\
\hline
\end{tabular}


розробки учнів задля отримання прибутку.

На прочесуально-діяльнісному етапі реалізації технології передбачається створення певного алгоритму, який систематизує дії як споживача освітньої послуги, так і організації, що такі послуги надає. Бажано при створенні такого алгоритму взяти до уваги індивідуальні потреби науково-педагогічного працівника, створити індивідуальну траєкторію оволодіння ним відповідною компетентністю (табл.5).

Таблиця 5

Алгоритм підвищення кваліфікації НПП у сфері охорони і захисту прав інтелектуальної власності (при наборі групи конкретизується за тижнями)

\begin{tabular}{|c|c|c|}
\hline $\begin{array}{l}\text { № } \\
3 / \Pi\end{array}$ & Зміст діяльності & Терміни \\
\hline \multicolumn{3}{|c|}{ 1. Підготовчо-діагностичний етап } \\
\hline 1. & $\begin{array}{lccc}\text { Ознайомлення слухачів із } & \text { завданнями } & \text { підготовчо- } \\
\text { діагностичного етапу технології } & & \end{array}$ & До початку навчання \\
\hline 2. & $\begin{array}{l}\text { Ознайомлення зі структурой та змістом компетентності } \\
\text { щодо охорони і захисту прав інтелектуальної власності НПП }\end{array}$ & До початку навчання \\
\hline 3. & 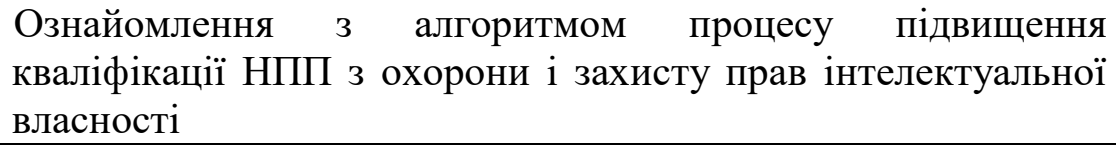 & До початку навчання \\
\hline 4. & $\begin{array}{l}\text { Ознайомлення НПП } 3 \text { варіантами навчальних планів } \\
\text { підвищення кваліфікації щодо охорони і захисту прав } \\
\text { інтелектуальної власності }\end{array}$ & До початку навчання \\
\hline 5. & $\begin{array}{l}\text { Вибір НПП навчального плану для підвищення кваліфікації } \\
\text { щодо охорони і захисту прав інтелектуальної власності }\end{array}$ & До початку навчання \\
\hline 6. & $\begin{array}{llll}\text { Оформлення } & \text { наказу } \\
\text { кваліфікації НПП } & \text { щодо } & \text { організації } & \text { підвищення } \\
\end{array}$ & До початку навчання \\
\hline 7. & Ознайомлення з інформаційною базою навчального процесу & На початку навчання \\
\hline 8. & $\begin{array}{l}\text { Представлення професорсько-викладацького } \\
\text { здійснюватиме підвищення кваліфікації НПП }\end{array}$ & На початку навчання \\
\hline 9. & $\begin{array}{l}\text { Ознайомлення слухачів } 3 \text { критеріями } \\
\text { результатів навчання }\end{array}$ & На початку навчання \\
\hline 10. & Вхідне діагностування слухачів & На початку навчання \\
\hline \multicolumn{3}{|c|}{ 2.Мотиваційно-цільвовий етап } \\
\hline 1. & $\begin{array}{l}\text { Мотиваційна підготовка слухачів щодо усвідомлення } \\
\text { необхідності компетентності щодо охорони і захисту прав } \\
\text { iнтелектуальної власності }\end{array}$ & $\begin{array}{l}\text { До i на початку } \\
\text { навчання }\end{array}$ \\
\hline 2. & Побудова слухачем індивідуального дерева цілей & На початку навчання \\
\hline 3. & $\begin{array}{l}\text { Реалізація системи заходів щодо мотивування слухачів на } \\
\text { формування компетентності щодо охорони і захисту прав } \\
\text { інтелектуальної власності }\end{array}$ & Протягом навчання \\
\hline
\end{tabular}




\begin{tabular}{|l|l|l|}
\hline 4. & $\begin{array}{l}\text { Стимулювання слухача курсів до саморозвитку й } \\
\text { самовдосконалення }\end{array}$ & Протягом навчання \\
\hline \multicolumn{3}{|c|}{ 3.когнітивний етап } \\
\hline 1. & Реалізація змістової складової в межах викладання теми 1 & Протягом навчання \\
\hline 2. & Реалізація змістової складової в межах викладання теми 2 & Протягом навчання \\
\hline 3. & $\begin{array}{l}\text { Реалізація змістової складової в межах викладання теми .. } \\
\text { в залежності від вибору навчального плану) }\end{array}$ & Протягом навчання \\
\hline \multicolumn{3}{|c|}{ 4.Процесуально-діяльнісний етап } \\
\hline 1. & $\begin{array}{l}\text { Реалізація форм, методів і засобів навчання, що дозволяють } \\
\text { максимально ефективно формувати компетентності щодо } \\
\text { охорони і захисту прав інтелектуальної власності }\end{array}$ & Протягом навчання \\
\hline 2. & $\begin{array}{l}\text { Розробка індивідуальних завдань для самостійної роботи } \\
\text { слухачів за кожною темою }\end{array}$ & Протягом навчання \\
\hline 3. & Підготовка матеріалів для випускної роботи слухача & Протягом навчання \\
\hline \multicolumn{3}{|c|}{ 5.Оцінно-корекційний етап } \\
\hline 1. & \begin{tabular}{l} 
Проведення поточних вимірювань за темою 1 \\
\hline 2.
\end{tabular} & $\begin{array}{l}\text { Проведення поточних вимірювань за темою 2 } \\
\text { вивчення теми 1 }\end{array}$ \\
\hline 3. & $\begin{array}{l}\text { Проведення поточних вимірювань за темою ... (в залежності } \\
\text { від вибору навчального плану) }\end{array}$ & $\begin{array}{l}\text { Після } \\
\text { вивчення теми ... }\end{array}$ \\
\hline 4. & Захист випускної роботи & $\begin{array}{l}\text { При виконні випускної } \\
\text { роботи }\end{array}$ \\
\hline 5. & Вихідне діагностування слухачів & Наприкінці навчання \\
\hline
\end{tabular}

На цьому ж етапі відбувається підбір доцільних форм і методів навчання 3 урахуванням створеної індивідуальної траєкторії споживача освітньої послуги. Слід наголосити, що при створенні індивідуальної траєкторії для кожного науково-педагогічного працівника необхідно взяти до уваги специфіку його викладацької та наукової діяльності та будувати процес підвищення кваліфікації так, щоб його результатом були конкретні авторські свідоцтва, патенти чи торгові марки.

Наголосимо, що на цьому етапі поряд із стандартними формами роботи шляхом прослуховування лекцій і виконання практичних робіт особливу увагу потрібно приділяти вирішенню компетентнісних задач, які суттєво впливають на якість кінцевого результату формування компетентності у сфері охорони $\mathrm{i}$ захисту прав інтелектуальної власності. Нижче, у ході висвітлення оціннокорекційного етапу технології, нами наведено приклади компетентнісної задачі та тестових завдань.

Особливу увагу треба звернути на можливість під час реалізації цього етапу використання напрацювання щодо трансферу певної методики, що суттєво вплине на специфіку діяльності на цьому етапі, бо передбачає специфічну процедуру оволодіння цією методикою. Питання трансферу 
педагогічних технологій і методик розглянуто нами в роботах (Luniachek \& Ruban, 2020; Luniachek, 2016).

На оцінно-корекиійному етапі технології відбувається процедура оцінювання сформованості компетентності в сфері охорони і захисту прав інтелектуальної власності. Авторами передбачається застосування спеціально створеної факторно-критеріальної моделі, розробленої на засадах кваліметричного підходу. Процедура створення такої моделі відображена нами у попередніх роботах (Luniachek, Ruban \& Kravchuk, 2020; Luniachek, Ruban \& Fesenko, 2018).

Підходи до оцінювання професійної компетентності сучасного фахівця у вищій школі грунтовно висвітлені в науковій літературі, зокрема це роботи Т. Борової, яка вказує, що компетентнісний підхід є більш продуктивним для оцінки професійного розвитку сучасного фахівця, дозволяє глибоко оцінити його професіоналізм (Borova, 2011).

Наголосимо, що найбільш складною частиною процедури оцінювання сформованості компетентності науково-педагогічного працівника в сфері охорони і захисту інтелектуальної власності $\epsilon$ розроблення інструментарію оцінювання. 3 цією метою авторами розроблена низка тестів, що мають спеціально-орієнтовані завдання, практичні завдання та компетентнісні задачі, які дозволяють вимірювати окремі складові компетентності, що розглядається (знання, уміння, навички та інші професійно важливі якості). Приклади тестових завдань наведено в табл. 6, компетентнісної задачі - в табл. 7.

Таблиця 6

Приклади тестових завдань, що входять до тесту

«Система інтелектуальної власності в Україні»

\begin{tabular}{|c|c|c|}
\hline $\begin{array}{l}\text { № } \\
\Pi / \Pi\end{array}$ & Зміст тестового завдання & Варіанти відповідей \\
\hline 1. & $\begin{array}{l}\text { В } \quad \text { наслідок чого } \\
\text { авторське право на твір? }\end{array}$ & $\begin{array}{l}\text { a) факту його створення; } \\
\text { б) факту його реєстрації; } \\
\text { в) факту його оприлюднення. }\end{array}$ \\
\hline 2. & Об’єктом авторського права є: & $\begin{array}{l}\text { a) повідомлення про новини дня або поточні } \\
\text { події, що мають характер звичайної прес- } \\
\text { інформації; } \\
\text { б) твори у галузі науки, літератури і } \\
\text { мистецтва; } \\
\text { в) твори народної творчості (фольклор). }\end{array}$ \\
\hline 3. & Співавтори - це: & $\begin{array}{l}\text { а) всі особи, які брали участь в оприлюдненні } \\
\text { твору; } \\
\text { б) особи, які замовили та фінансували } \\
\text { створення твору; }\end{array}$ \\
\hline
\end{tabular}




\begin{tabular}{|l|l|l|}
\hline 4. & $\begin{array}{l}\text { Твори науки, літератури i } \\
\text { мистецтва після закінчення строку } \\
\text { їх правової охорони: }\end{array}$ & $\begin{array}{l}\text { a) стають надбанням нащадків; } \\
\text { б) стають надбанням суспільства; } \\
\text { в) можна подовжити термін їх дії. }\end{array}$ \\
\hline 5. & $\begin{array}{l}\text { Який термін дії майнових прав на } \\
\text { авторське право? }\end{array}$ & $\begin{array}{l}\text { а) протягом 70 років; } \\
\text { б) протягом всього житт; } \\
\text { в) протягом всього життя автора і } 70 \text { років } \\
\text { після його смерті. }\end{array}$ \\
\hline 6. & $\begin{array}{l}\text { Об’єктом промислового зразка } \\
\text { може бути: }\end{array}$ & $\begin{array}{l}\text { a) малюнок; } \\
\text { б) пристрій; } \\
\text { в) розфарбування. }\end{array}$ \\
\hline 7. & Об’єктами винаходу можуть бути: & $\begin{array}{l}\text { а) художні твори, картини, фонограми, бази } \\
\text { даних, топографії інтегральних мікросхем; } \\
\text { б) торговельні марки, фірмові найменування, } \\
\text { сорти рослин, породи тварин; } \\
\text { в) пристрій, спосіб, речовина, штам } \\
\text { мікроорганізму. }\end{array}$ \\
\hline
\end{tabular}

Таблиця 7

Приклад компетентнісної задачі за темою «Набуття права інтелектуальної власності»

\begin{tabular}{|l|l|}
\hline \multicolumn{1}{|c|}{ Зміст компетентнісної задачі } & Критерії оцінювання \\
\hline $\begin{array}{l}\text { Ситуація - студенти спеціальності «Дизайн» в результаті виконання } \\
\text { курсової роботи підготували колекцію суконь, вирішили отримати } \\
\text { охоронні документи на оригінальні елементи одягу, які втілились як } \\
\text { у зовнішньому вигляді, так і в технології крою. } \\
\text { компетентнісна задача - визначити правовий режим охорони } \\
\text { інтелектуальної власності на створені екземпляри і елементи одягу } \\
\text { та обгрунтувати, які охоронні документи треба підготувати та хто } \\
\text { буде патентовласником? }\end{array}$ & \\
\hline
\end{tabular}

Важливою складовою цього етапу є розробка підходів щодо інтерпретації результатів вимірювання сформованості компетентності у сфері охорони i захисту прав інтелектуальної власності, що є важливою складовою процедури педагогічного оцінювання. Автори пропонують використовувати для проведення оцінки не тільки стандартні шкали, що відображені сьогодні в науковій літературі, наприклад:

$0<\mathrm{P}_{\text {заг. }} \leq 0,5$ - сформованість компетентностей $\epsilon$ недостатньою;

$0,5<\mathrm{P}_{\text {заг. }} \leq 0,74$ - сформованість компетентностей є задовільною;

$0,74<\mathrm{P}_{\text {заг. }} \leq 0,89$ - сформованість компетентностей є достатньою;

$0,90<\mathrm{P}_{\text {заг. }} \leq 1$ - сформованість компетентностей є оптимальною (Kuruch, 2019; Luniachek, 2012; Mirshuk, 2016; Moiseev \& Hvan, 2005). 
Пропонується проведення оцінювання за напрямами за 10-бальною шкалою, наприклад (табл. 8):

Таблиця 8

Спроможність оформити документи щодо отримання авторського свідоцтва на твір

\begin{tabular}{|c|c|c|c|c|c|c|c|c|c|}
\hline 1 & 2 & 3 & 4 & 5 & 6 & 7 & 8 & 9 & 10 \\
\hline- & - & - & - & - & - & - & $*$ & - & - \\
\hline
\end{tabular}

Після проведення такого оцінювання в обов'язковому порядку формуються індивідуальні рекомендації науково-педагогічному працівнику щодо прогалин у його знаннях для подальшої корекції у формуванні компетентності, що розглядається.

Підводячи підсумки, наголосимо, що в умовах пандемії набуло актуальності розроблення дистанційних курсів, націлених на формування в процесі підвищення кваліфікації професійної компетентності НПП у сфері охорони і захисту прав інтелектуальної власності. Приклад такого курсу наведено на рис. 1.

$\equiv$ дО УІПА

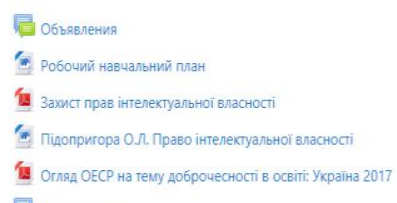

扂 обьввенияя

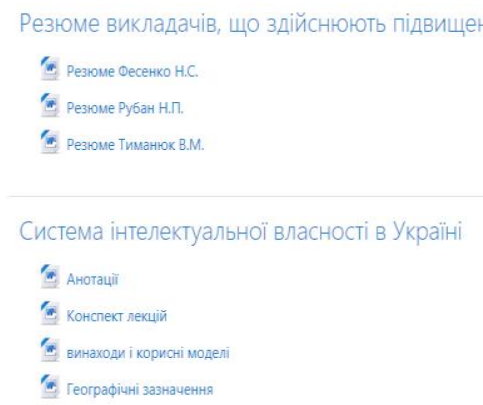

Рис.1. Дистанщійний курс «Підвищення кваліфікащії з методики управління об'єктами інтелектуальної власності» 
Зазначений курс було розроблено фахівцями кафедри креативної педагогіки й інтелектуальної власності Української інженерно-педагогічної академії.

Обговорення. У цій роботі, виходячи з наших попередніх досліджень, ми під закономірностями процесу підвищення кваліфікації науково-педагогічних у сфері охорони і захисту прав інтелектуальної власності розуміємо об'єктивні, стійкі й істотні зв'язки між системою професійного розвитку науковопедагогічних працівників як суб'єктів інноваційного процесу і їх спроможністю в наукових, методичних та інших інноваційних розробках виявляти, охороняти і захищати об'єкти інтелектуальної власності (OIB).

Відповідно у цій роботі ми тлумачимо педагогічні принципи як систему положень, що базуються на педагогічних закономірностях, визначають зміст, форми, методи підвищення кваліфікації тощо, тобто стратегію вирішення проблеми підвищення кваліфікації науково-педагогічних у сфері охорони і захисту прав інтелектуальної власності i мають системоутворювальний характер.

У контексті цієї роботи ми розглядаємо педагогічні умови як систему необхідних обставин, які дозволяють сформувати компетентність щодо охорони і захисту прав інтелектуальної власності в науково-педагогічних працівників 3ВО в процесі підвищення кваліфікації.

Таким чином, огляд теоретичних джерел дозволяє зробити висновок, що в сучасній педагогіці, зокрема педагогіці вищої школи, достатньо грунтовно розроблені науково-теоретичні засади процесу підвищення кваліфікації, разом iз тим нагальною потребою часу $\epsilon$ їх подальша розробка в контексті формування окремих компетентностей за актуальними сьогодні напрямами, одним 3 яких є охорона і захист прав інтелектуальної власності.

\section{Висновки:}

1. Проведений аналіз науково-теоретичних джерел свідчить, що серед них бракує робіт, спрямованих на теоретичне обгрунтування формування певних професійних компетентностей науково-педагогічних працівників, які $\epsilon$ сьогодні на часі, зокрема й компетентності у сфері охорони і захисту прав інтелектуальної власності.

2. Нагальною потребою часу є також проведення науково-комунікативних заходів, присвячених формуванню окремих професійних компетентностей, що передбачають специфічне змістовне наповнення та мають міждисциплінарний характер. 
3. Важливим аспектом проблеми, що розглянута в роботі, є мотивація науково-педагогічних працівників на отримання послуги щодо формування в них компетентності у сфері охорони і захисту прав інтелектуальної власності. Слід привернути увагу керівництва закладів вищої освіти на формування відповідних факторів-мотиваторів у процесі розробки планів інноваційного розвитку ЗВО.

4. Запровадження запропонованої в роботі технології є можливим тільки як результат розроблених педагогічних умов, реалізація яких повинна бути серед пріоритетів діяльності керівництва ЗВО.

5. У ситуації переходу значної кількості ЗВО в умовах пандемії на дистанційні форми роботи, актуальним є розроблення дистанційного курсу щодо формування в науково-педагогічних працівників компетентності в сфері охорони і захисту прав інтелектуальної власності.

Перспективним напрямом досліджень цієї проблематики $є$ розробка технологій оволодіння компетентністю в сфері охорони і захисту прав інтелектуальної власності для науково-педагогічних працівників, що спеціалізуються на підготовці фахівців для певних галузей економіки України.

\section{ЛIТЕРАТУРА:}

Luniachek V., Varenko T. Postgraduate Pedagogical Education in Ukraine [Electronic Resource]. Urban Studies and Public Administration. 2018. Vol. 1, No. 2. P. 199-209. Режим доступу : - http://www.scholink.org/ojs/index.php/uspa/article/view/1559/1706 - Дата звернення 20.10.2020 p.

Professional Development of Ukrainian Higher Education Staff in Intellectual Property: monograph. ed. V. Luniachek. Kindle Direct Publishing Platform, 2020. 138 p.

Бабанский Ю. К. Оптимизация педагогического процесса : (в вопр. и ответах). 2-е изд., перераб. и доп. К. : Радянська школа, 1983. 287 с.

Бєляєв С. Б. Професійна підготовка майбутніх учителів до розробки і використання педагогічних технологій: монографія. Х. : Видавець СПД-ФО Захарченко В. В., 2019. $410 \mathrm{c}$

Борова Т. А. Теоретичні засади адаптивного управління професійним розвитком науковопедагогічних працівників вищого навчального закладу : монографія. Х. : СМIT, 2011. $384 \mathrm{c}$.

Гуцан Т. Г. Педагогічні умови формування готовності майбутніх вчителів економіки до профільного навчання старшокласників. [Електронний ресурс]. Режим доступу : http://intkonf.org/gutsan-tg-pedagogichni-umovi-formuvannya-gotovnosti-maybutnihvchiteliv-ekonomiki-do-profilnogo- navchannya-starshoklasnikiv/ - Дата звернення 05.11.2020 p.

Деякі питання підвищення кваліфікації педагогічних і науково-педагогічних працівників [Електронний ресурс] : Постанова Каб-ту М-в України № 800 від 21.08.2019 р. (із $\begin{array}{lllllll}\text { змінами № } 1133 \text { від } 27.12 .2019 & \text { р.). }\end{array}$ https://zakon.rada.gov.ua/laws/show/800-2019-\%D0\%BF - Дата звернення 10.11.2020 p.

Енциклопедія освіти. [голов. ред. В. Г. Кремень]. К. : Юрінком Інтер, 2008. 1040 с. 
Завалевский Ю. I. Теоретико-методичні засади формування вчителя як конкурентоспроможного фахівця : монографія. Чернівці : Букрек, 2014. 416 с.

Інтелектуальна власність очима працівників освіти (за результатами соціологічного опитування (код ДК-021:2015-97320000-3) згідно з договором № 87-II від 27.05.2019) : аналітичний звіт. Х. УІПА, 2019. 78 с.

Компетентнісний вимір професійного розвитку працівників освіти в сфері інтелектуальної власності : монографія. За заг. ред. В. Е. Лунячека. Х. : ТОВ «Оберіг», 2020. 368 с.

Куруч А. В. Формування політичної компетентності у курсантів вищих військових навчальних закладів : дис. ... канд. пед. наук : 13.00.04 - теорія і методика професійної освіти. Харків: УІПА, 2019. 287 с.

Лунячек В. Е. Реалізація положень Закону України «Про освіту» в процесі підвищення кваліфікації педагогічних працівників: моделі і організаційні механізми. Проблеми інженерно-педагогічної освіти: зб. наук. пр. Х. : УІПА, 2020. Вип. 56-57, С. 58-67.

Лунячек В. Е. Теоретико-методологічні засади професійної підготовки керівних кадрів в умовах магістратури до управління якістю освіти : дис. ... д-ра пед. наук: 13.00.04. Х. : ХНПУ імені Г. С. Сковороди, 2012. 400 с.

Лунячек В. Е. Трансфер технологій як складова процесу підвищення кваліфікації керівників освіти. Проблеми інженерно-педагогічної освіти: зб. наук. пр. Х. УІПА, 2020. Вип. 5253. C. 201-210.

Лунячек В. Е., Рубан Н. П. Трансфер технологій як форма підвищення кваліфікації працівників освіти. Розбудова єдиного відкритого інформаційного простору освіти впродовж життя : зб. матеріалів 2-го Міжнар. наук.-практ. WEB-форуму (КиївХарків, 25-27 берез. 2020 р.). Х., 2020. Вип. 2. С. 86-89.

Лунячек В. Е., Рубан Н. П., Фесенко Н. С. Професійний розвиток працівників системи загальної середньої освіти в сфері інтелектуальної власності : монографія. Х. : ФОП Панов, 2018. 224 c.

Лунячек В. Е. Компетентнісний підхід як методологія професійної підготовки у вищій школі. Публічне управління: теорія та практика. 2013. № 1 (13). С. 155-162.

Лунячек В. Компетентнісний підхід як методологія професійного розвитку працівника освіти. Нова педагогічна думка. 2020. №2 (102). С. 37-45.

Лунячек В., Рубан Н., Кравчук Л. Оцінювання сформованості компетентності в сфері охорони і захисту прав інтелектуальної власності у працівників закладів загальної середньої освіти засобами кваліметрії. Проблеми інженерно-педагогічної освіти : зб. наук. пр. Х. : УІПА, 2020. Вип. 67. С. 108-119.

Лунячек В. Е., Рубан Н. П., Нечуйвітер О. П. Оцінювання сформованості компетентності в сфері охорони і захисту прав інтелектуальної власності у викладачів 3ВО засобами кваліметрії. Проблеми інженерно-педагогічної освіти: зб. наук. пр. Х. : УІПА, 2020. Вип. 68.

Майоров А. Н. Мониторинг в образовании. Изд. 3-е, испр. и доп. М. : Интеллект-центр, 2005. $424 \mathrm{c}$.

Мескон М. Основы менеджмента : [пер. с англ.]. М. : Дело, 1994. 702 с.

Методика навчання і наукових досліджень у вищій школі : [навч. посіб.]. За ред. С. У. Гончаренка, П. М. Олійника. К. : Вища школа, 2003. 323 с.

Михайловский В. А. Педагогика высшей школы : учеб. пособие. Х. : ХГУ, 1991. 187 с.

Міршук О. С. Професійна підготовка магістрів військово-соціального управління до педагогічної діяльності : дис. ... канд. пед. наук : 13.00 .04 - теорія і методика професійної освіти. Х. : УІПА, 2016. 322 с.

Москалець М. М., Швидун В. М. Розвиток професійних компетентностей учителів в умовах реформування української школи в системі післядипломної педагогічної освіти. Нова педагогічна думка. 2018. № 3. С. 25-29. 
Підвищення кваліфікації педагогічних працівників на базі науково-методичного центру міста : [рекомендації з організації роботи]. К. : Асоціація міст України. 28 с.

Післядипломна педагогічна освіта в умовах децентралізації та модернізації: регіональний аспект : монографія. За заг. ред. В. С. Береки. Хмельницький : ФОП Мельник А. А., 2017. $548 \mathrm{c}$.

Поташник М. М., Моисеев А. М. Управление современной школой (в вопросах и ответах) : [пособие для рук. образоват. учреждений и органов образования]. М. : Новая школа, 1997. $352 \mathrm{c}$.

Про вищу освіту [Електронний ресурс] : Закон України № 1556-VII від 1.07.2014 р. (зі змінами). - Режим доступу : https://zakon.rada.gov.ua/laws/show/1556-18\#Text - Дата звернення 01.11.2020 p.

Про освіту [Електронний ресурс] : Закон України № 2145-VIII від 05.09.2017 р. (зі змінами). - Режим доступу : https://zakon.rada.gov.ua/laws/show/2145-19\#Tеxt - Дата звернення 01.11.2020 p.

Селевко Г. К. Педагогические технологии на основе активизации, интенсификации и эффективного управления УВП. М. : НИИ школьных технологий, 2005. 288 с.

Сидоренко В. В., Скрипник М. I. Курикулум підвищення кваліфікації педагогічних працівників в України: підходи та особливості розроблення [Електронний ресурс]. Адаптивне управління: теорія і практика. Серія : Педагогіка. 2017. № 3 (5). Режим доступу : http://am.eor.in.ua/images/adapt/Vol.3ped5/17ped3_5sidorenko_r.pdf - Дата звернення 08.11.2020p.

Словарь иностранных слов. 14-е изд., испр. М. : Русский язык, 1987. 608 с.

Сорочан Т. М. Феномен педагогічної майстерності як методологія трансформації професіоналізму педагогів Нової української школи. Педагогіка і психологія. 2019. № 1 (102). C. 5-13.

Управление школой: слов.-справ. рук. образовательного учреждения. Под ред. А. М. Моисеева, А. А. Хвана. М. : Педагогическое общество России, 2005. 320 с.

Фіцула М. М. Педагогіка : навч. посіб. для студ. вищих пед. закладів освіти. К. : Академія, 2000. $544 \mathrm{c}$.

Чеботарьова I. О. Формування комунікативної компетентності майбутніх керівників закладів освіти в умовах магістратури : дис. ... канд. пед. наук : 13.00 .04 - теорія і методика професійної освіти. Х., 2018. 240 с.

Швидун В. М. Управління післядипломною педагогічною освітою як складовою освіти в Україні. Нова педагогічна думка. 2019. № 3. С. 48-51.

\section{REFERENCES:}

Babanskij, Ju. K \& Potashnik, M. M. (1983), Optimizacija pedagogicheskogo processa. [Optimization of the pedagogical process: (in questions and answers)], 2nd edn, Radjanska shkola, Kiev (in Russian).

Bereka, V. Ye. (Ed.) (2017). Pisliadyplomna pedahohichna osvita v umovakh detsentralizatsii ta modernizatsii: rehionalnyi aspect. [Postgraduate pedagogical education in the context of decentralization and modernization: regional aspect], FOP Melnyk AA, Khmelnytskyi (in Ukranian).

Bieliaiev, S. B. (2019). Profesiina pidhotovka maibutnikh uchyteliv do rozrobky $i$ vykorystannia pedahohichnykh tekhnolohii. [Professional training of future teachers for the development and use of pedagogical technologies], Vydavets SPD-FO Zakharchenko V.V., Kharkiv (in Ukranian).

Borova, T. A. (2011). Teoretychni zasady adaptyvnoho upravlinnia profesiinym rozvytkom naukovo-pedahohichnykh pratsivnykiv vyshchoho navchalnoho zakladu. [Theoretical bases 
of adaptive management of professional development of scientific and pedagogical workers of higher educational institution], SMIT, Kharkiv (in Ukranian).

Chebotarova, I. O. (2018). 'Formuvannia komunikatyvnoi kompetentnosti maibutnikh kerivnykiv zakladiv osvity $v$ umovakh mahistratury' [Formation of communicative competence of future heads of educational institutions in the conditions of a magistracy], (Candidate's thesis), Ukrainska inzhenerno-pedahohichna akademiia, Kharkiv (in Ukranian).

Fitsula, M. M. (2000). Pedahohika. [Pedagogy], Akademiia, Kyiv (in Ukranian).

Honcharenko, S. U., Oliinyk, P. M. \& Fedorchenko, V. K. (2003). Metodyka navchannia $i$ naukovykh doslidzhen $u$ vyshchii shkoli. [Methods of teaching and research in higher education]. Vyshcha shkola, Kyiv (in Ukranian).

Hutsan, T. H. (n. d.). Pedahohichni umovy formuvannia hotovnosti maibutnikh vchyteliv ekonomiky do profilnoho navchannia starshoklasnykiv. [Pedagogical conditions for the formation of readiness of future teachers of economics for specialized training of high school students], viewed 05 November 2020, <http://intkonf.org/gutsan-tg-pedagogichni-umoviformuvannya-gotovnosti-maybutnih-vchiteliv-ekonomiki-do-profilnogo- navchannyastarshoklasnikiv/> (in Ukranian).

Kabinet Ministriv Ukrainy (2019) Deiaki pytannia pidvyshchennia kvalifikatsii pedahohichnykh $i$ naukovo-pedahohichnykh pratsivnykiv [Some issues of professional development of pedagogical and scientific-pedagogical workers]: Postanova no. 800 vid 21.08.2019 roku (iz zminamy no. 1133 vid 27.12.2019 roku), viewed 10 November 2020, <https://zakon.rada.gov.ua/laws/show/800-2019-\%D0\%BF> (in Ukranian).

Kovalenko, O., Luniachek, V., Fesenko, N., Timaniuk, V., Rubashka, V., Ruban, N., Brovdii, A. \& Kulakovskyi, O. (2020). Professional Development of Ukrainian Higher Education Staff in Intellectual Property, Kindle Direct Publishing Platform.

Kremen, V.H. (Ed.) (2008). Entsyklopediia osvity [Encyclopedia of Education], Akademiia pedahohichnykh nauk Ukrainy, Yurinkom Inter, Kyiv (in Ukranian).

Kuruch, A. V. (2019). 'Formuvannia politychnoi kompetentnosti u kursantiv vyshchykh viiskovykh navchalnykh zakladiv' [Formation of political competence in cadets of higher military educational institutions], (Candidate's thesis), Ukrainska inzhenerno-pedahohichna akademiia, Kharkiv (in Ukranian).

Luniachek, V. \& Varenko, T. (2018). 'Postgraduate Pedagogical Education in Ukraine', Urban Studies and Public Administration, vol. 1, no. 2, pp. 199-209, viewed 20 October 2020, <http://www.scholink.org/ojs/index.php/uspa/article/view/1559/1706>.

Luniachek, V. (2020). 'Kompetentnisnyi pidkhid yak metodolohiia profesiinoho rozvytku pratsivnyka osvity' [Competence approach as a methodology of professional development of an educator]. Nova pedahohichna dumka, ROIPPO, Rivne, no. 2 (102), pp. 37-45 (in Ukranian).

Luniachek, V. E. \& Ruban, N. P. (2020). 'Transfer tekhnolohii yak forma pidvyshchennia kvalifikatsii pratsivnykiv osvity' [Technology transfer as a form of professional development of educators]. Rozbudova yedynoho vidkrytoho informatsiinoho prostoru osvity vprodovzh zhyttia, Kharkiv, iss. 2, pp. 86-89 (in Ukranian).

Luniachek, V. E. (2017). 'Realizatsiia polozhen Zakonu Ukrainy Pro osvitu v protsesi pidvyshchennia kvalifikatsii pedahohichnykh pratsivnykiv: modeli $i$ orhanizatsiini mekhanizmy' [Implementation of the provisions of the Law of Ukraine "On Education" in the process of professional development of teachers: models and organizational mechanisms]. Problemy inzhenerno-pedahohichnoi osvity, Ukrainska inzhenernopedahohichna akademiia, Kharkiv, iss. 56-57, pp. 58-67 (in Ukranian).

Luniachek, V. E., Ruban, N. P. \& Brovdii, A. M. (2020). Kompetentnisnyi vymir profesiinoho rozvytku pratsivnykiv osvity $v$ sferi intelektualnoi vlasnosti [Competence dimension of 
professional development of educators in the field of intellectual property], Oberih, Kharkiv (in Ukranian).

Luniachek, V. E., Ruban, N. P. \& Nechuiviter, O. P. (2020). 'Otsiniuvannia sformovanosti kompetentnosti $v$ sferi okhorony $i$ zakhystu prav intelektualnoi vlasnosti u vykladachiv ZVO zasobamy kvalimetrii' [Assessment of the formation of competence in the field of protection and enforcement of intellectual property rights in teachers of free economic science by means of qualimetry]. Problemy inzhenerno-pedahohichnoi osvity, Ukrainska inzhenernopedahohichna akademiia, Kharkiv, iss. 68. (in Ukranian).

Luniachek, V. E, Ruban, N. P. \& Fesenko, N. S. (2018). Profesiinyi rozvytok pratsivnykiv systemy zahalnoi serednoi osvity $v$ sferi intelektualnoi vlasnosti. [Professional development of employees of the general secondary education system in the field of intellectual property]. FOP Panov, Kharkiv (in Ukranian).

Luniachek, V.E. (2012). 'Teoretyko-metodolohichni zasady profesiinoi pidhotovky kerivnykh kadriv $v$ umovakh mahistratury do upravlinnia yakistiu osvity' [Theoretical and methodological principles of professional training of managers in the conditions of master's degree in education quality management]. (Doctor's thesis), Kharkivskyi natsionalnyi pedahohichnyi universytet imeni HS Skovorody, Kharkiv (in Ukranian).

Luniachek, V. E. (2013). 'Kompetentnisnyi pidkhid yak metodolohiia profesiinoi pidhotovky u vyshchii shkoli. [Competence approach as a methodology of professional training in higher education], Publichne upravlinnia: teoriia ta praktyka, no. 1 (13), pp. 155-162 (in Ukranian).

Luniachek, V. E. (2016). 'Teoretyko-metodolohichni zasady profesiinoi pidhotTransfer tekhnolohii yak skladova protsesu pidvyshchennia kvalifikatsii kerivnykiv osvity'. [Technology transfer as a component of the process of professional development of education managers]. Problemy inzhenerno-pedahohichnoi osvity, Ukrainska inzhenerno-pedahohichna akademiia, Kharkiv, iss. 52-53, pp. 201-210 (in Ukranian).

Luniachek, V. E., Ruban, N. P. \& Kravchuk, N. L. (2020). 'Otsiniuvannia sformovanosti kompetentnosti $\mathrm{v}$ sferi okhorony i zakhystu prav intelektualnoi vlasnosti u pratsivnykiv zakladiv zahalnoi serednoi osvity zasobamy kvalimetrii' [Assessment of the formation of competence in the field of protection and enforcement of intellectual property rights of employees of general secondary education by means of qualimetry]. Problemy inzhenernopedahohichnoi osvity, Ukrainska inzhenerno-pedahohichna akademiia, Kharkiv, iss. 67, pp.108-119 (in Ukranian).

Majorov, A. N. (2005). Monitoring v obrazovanii. [Monitoring in education], 3nd edn, Intellektcentr, Moskva (in Russian).

Meskon, M., Albert, M. \& Hedouri, F. (1994). Osnovy menedzhmenta. [Fundamentals of management], Delo, Moskva (in Russian).

Mihajlovskij, V. A. (1991) Pedagogika vysshej shkoly. [Pedagogy of high school], Harkovskij gosudarstvennyj universitet, Harkov (in Russian).

Mirshuk, O. Ie. (2016). 'Profesiina pidhotovka mahistriv viiskovo-sotsialnoho upravlinnia do pedahohichnoi diialnosti' [Professional training of masters of military and social management for pedagogical activity]. (Candidate's thesis), Ukrainska inzhenernopedahohichna akademiia, Kharkiv (in Ukranian).

Moiseev, A. M. \& Hvan, A. A. (Eds.) (2005). Upravlenie shkoloj [School management], Pedagogicheskoe obshhestvo Rossii, Moskva (in Russian).

Moskalets, M. M. \& Shvydun, V. M. (2018). 'Rozvytok profesiinykh kompetentnostei uchyteliv $v$ umovakh reformuvannia ukrainskoi shkoly $v$ systemi pisliadyplomnoi pedahohichnoi osvity' [Development of professional competencies of teachers in the conditions of reforming the Ukrainian school in the system of postgraduate pedagogical education], Nova pedahohichna dumka, no. 3 (95), pp. 25-29 (in Ukranian). 
Mozghova, L., Pokhyliak, O., Lytvyniuk, H. \& Svinnykh, H. (2019). Pidvyshchennia kvalifikatsii pedahohichnykh pratsivnykiv na bazi naukovo-metodychnoho tsentru mista. [Advanced training of pedagogical workers on the basis of the scientific and methodical center of the city], Asotsiatsiia mist Ukrainy, Kyiv (in Ukranian).

Potashnik, M. M. \& Moiseev, A. M. (1997). Upravlenie sovremennoj shkoloj (v voprosah $i$ otvetah). [Management of a modern school (in questions and answers)], Novaja shkola, Moskva (in Russian).

Prezydent Ukrainy (2014). Zakon Ukrainy Pro vyshchu osvitu [About higher education] no. 1556VII vid 1.07.2014 roku (zi zminamy), viewed 01 November 2020, <https://zakon.rada.gov.ua/laws/show/1556-18\#Text> (in Ukranian).

Prezydent Ukrainy (2017). Zakon Ukrainy Pro osvitu [About education] no. 2145-VIII vid 05.09.2017 roku (zi zminamy), viewed 01 November 2020, $<$ https://zakon.rada.gov.ua/laws/show/2145-19\#Text> (in Ukranian).

Selevko, G. K. (2005). Pedagogicheskie tehnologii na osnove aktivizacii, intensifikacii $i$ jeffektivnogo upravlenija UVP. [Pedagogical technologies based on activation, intensification and effective management of the educational process], Nauchnoissledovatelskij institut shkolnyh tehnologij, Moskva (in Russian).

Shvydun, V. M. (2019). 'Upravlinnia pisliadyplomnoiu pedahohichnoiu osvitoiu yak skladovoiu osvity $v$ Ukraini'. [Management of postgraduate pedagogical education as a component of education in Ukraine], Nova pedahohichna dumka, no. 3 (99), pp. 48-51 (in Ukranian).

Slovar inostrannyh slov (1987). [Dictionary of foreign words], 14th edn, Russkij jazyk, Moskva (in Russian).

Sorochan, T. M. (2019). Fenomen pedahohichnoi maisternosti yak metodolohiia transformatsii profesionalizmu pedahohiv Novoi ukrainskoi shkoly' [The phenomenon of pedagogical skill as a methodology of transformation of professionalism of teachers of the New Ukrainian school], Pedahohika i psykholohiia, no. 1 (102), pp. 5-13. (in Ukranian).

Sydorenko, V. V. \& Skrypnyk, M. I. (2017). 'Kurykulum pidvyshchennia kvalifikatsii pedahohichnykh pratsivnykiv v Ukrainy: pidkhody ta osoblyvosti rozroblennia' [Curriculum for the promotion of the qualifications of pedagogical workers in Ukraine: approaches and special features of the development], Adaptyvne upravlinnia: teoriia i praktyka, Seriia $\begin{array}{lllll}\text { Pedahohika, } & \text { no. } & 3 & (5), & \text { viewed }\end{array}$ November 2020, <http://am.eor.in.ua/images/adapt/Vol.3ped5/17ped3_5sidorenko_r.pdf> (in Ukranian).

Ukrainska inzhenerno-pedahohichna akademiia (2019) Intelektualna vlasnist ochyma pratsivnykiv osvity (za rezultatamy sotsiolohichnoho opytuvannia (kod DK-021:2015-97320000-3). [Intellectual property through the eyes of educators (according to the results of a poll)] zghidno z dohovorom № 87-II vid 27.05.2019) : analitychnyi zvit, Kharkiv (in Ukranian).

Zavalevskyi, Yu. I. (2014). Teoretyko-metodychni zasady formuvannia vchytelia yak konkurentospromozhnoho fakhivtsia. [Theoretical and methodological principles of teacher formation as a competitive specialist], Bukrek, Chernivtsi (in Ukranian).

\begin{tabular}{|c|c|}
\hline Інфор & S: \\
\hline Лунячек Вадим Едуардович: ORCID & Luniachek Vadym Ed \\
\hline 0000-0002-4412-7068, доктор педагогічних & tor of Pedagogical \\
\hline наук, професор, завідувач кафедри & ssor, Head of \\
\hline педагогіки і & and Intellectual \\
\hline Українська & Ukrainian Engineering \\
\hline $\begin{array}{l}\text { педагогічна академія, вул. Університетська } \\
16, \text { м. Харків, Україна, 61003. }\end{array}$ & $\begin{array}{l}\text { Pedagogics Academy, Universytetska Street, } \\
\text { 16, Kharkiv, Ukraine, } 61003 \text {. }\end{array}$ \\
\hline
\end{tabular}


Рубан Наталія Павлівна: ORCID 0000- Ruban Nataliia Pavlivna: ORCID 00000001-8337-2739, кандидат педагогічних 0001-8337-2739, Candidate of Pedagogical наук, доцент кафедри креативної педагогіки Sciences, Docent, Department of Creative i інтелектуальної власності, Українська Pedagogy and Intellectual Property, Ukrainian інженерно-педагогічна академія, вул. Engineering Pedagogics Academy, Університетська, 16, м. Харків, Україна, Universytetska Street, 16, Kharkiv, Ukraine, 61003. 61003.

e-mail: ruban_73@ukr.net

e-mail: ruban_73@ukr.net

Цитуйте цю статтю як: Лунячек В.Е., Рубан Н.П. Підвищення кваліфікації науковопедагогічних працівників закладів вищої освіти в сфері інтелектуальної власності: закономірності, принципи, педагогічні умови та основи технології. Теорія та методика навчання та виховання. 2020. № 49. С. 113-127.

DOI: https://doi.org/10.34142/23128046.2020.49.13

Дата надходження статті до редакції: 11.11 .2020 p.

Стаття прийнята до друку: 26.11.2020 p. 